\section{$\underset{\substack{\text { hommes } \\ \text { \& migrations }}}{ }$}

\section{Hommes \& migrations}

Revue française de référence sur les dynamiques

migratoires

$1294 \mid 2011$

L'intégration en débat

\title{
Des vents contraires
}

Film français de Jalil Lespert

\section{André Videau}

\section{OpenEdition \\ 1 Journals}

\section{Édition électronique}

URL : http://journals.openedition.org/hommesmigrations/594

DOI : 10.4000/hommesmigrations.594

ISSN : 2262-3353

\section{Éditeur}

Musée national de l'histoire de l'immigration

\section{Édition imprimée}

Date de publication : 1 novembre 2011

Pagination : 139

ISSN : 1142-852X

\section{Référence électronique}

André Videau, «Des vents contraires », Hommes \& migrations [En ligne], 1294 | 2011, mis en ligne le 29 mai 2013, consulté le 22 septembre 2020. URL : http://journals.openedition.org/hommesmigrations/ 594 ; DOI : https://doi.org/10.4000/hommesmigrations.594

Ce document a été généré automatiquement le 22 septembre 2020.

Tous droits réservés 


\title{
Des vents contraires
}

\author{
Film français de Jalil Lespert
}

\section{André Videau}

1 Pour son deuxième passage à plein-temps derrière la caméra, tentation récurrente pour de nombreux jeunes comédiens, après Vingt-quatre mesures (2007), Jalil Lespert, valeur sûre de la jeune génération - Nos vies heureuses de Jacques Maillot (1999), Un dérangement considérable de Bernard Stora (2000), Ressources humaines de Laurent Cantet (2000), Le petit lieutenant de Xavier Beauvois (2005), Le promeneur du Champ-de-Mars de Robert Guédiguian (2005)... -, a pris la solide garantie de l'adaptation d'un roman à succès d'Olivier Adam. Il réussit un film attachant.

2 Cela au prix de quelques modifications, mais surtout grâce à une touche de sensibilité personnelle et à cette empathie naturelle que certains acteurs récemment convertis à la réalisation semblent éprouver pour leurs interprètes, et qui les guide dans une direction aux limites du fusionnel. À titre d'exemple, il y a longtemps que Benoît Magimel n'avait été aussi bon. Parfois engagé dans des aventures hasardeuses, soit heurtant de façon pas toujours probante son tempérament difficile à maîtriser, soit s'y pliant de façon docile et conventionnelle. Il n'a pas été toujours facile d'être un exenfant prodige, plongé dans le cinéma depuis l'âge de seize ans, comme dans "un long fleuve tranquille"! Son statut de père abandonné et d'écrivain en panne lui permet une salutaire mutation. Son goût pour le romanesque fictionnel l'entraîne vers des paroxysmes où s'affrontent le père, le frère, le fils, le mari éconduit, l'ami, entourés d'une kyrielle de personnages secondaires, tous traités avec déférence et interprétés avec des exigences et des profondeurs de rôles majeurs.

Qu'est-ce qui n'a pas tourné rond dans l'existence de Paul Anderen? Sa carrière littéraire, suivie avec conviction par son éditeur (Daniel Duval), ne connaît que les difficultés normales de la création. Outre qu'elle lui a donné deux beaux enfants, Clément et Manon (Hugo Fernandez et Cassiopée Mayance), sa femme Sarah (Audrey Tautou), médecin cancérologue réputé, pourvoit au standing du couple. Et puis soudain Sarah disparaît et tous les repères se brisent.

4 Le film bascule et s'exile de Paris à Saint-Malo. Le héros se clochardise, s'humanise, renoue avec la famille (son frère, humble garagiste jadis méprisé : Antoine Duléry), se 
solidarise avec d'autres exclus, comme sortis des romans de Kérouac, Carver ou John Fante, comme ce père, déchu de ses droits paternels et qui en mourra, sous les yeux de son fils (sublimé par la présence de Azzedine Bouabba, Ramzy Bédia se livre au plus stupéfiant des contre-emplois); comme ce fantastique clochard mobil-homesque présumé assassin (Bouli Lanners). Sans oublier les femmes que captive ce séducteur maladroit, veuf à jamais: Aurore Clément, la féerique voisine, Marie-Ange Casta, troublante et troublée, trop jeune élève de l'auto-école, Isabelle Carré, la policière touchée au cœur, Lubna Azabal, victime impitoyable...

5 Vous aurez du mal à résister à ces vents contraires. Ils en valent la peine. Au-delà des tourments et des tornades, Jalil Lespert et ses comédiens inspirés nous apportent un air plus tonique. On aime ça. 